\title{
Toll-Like Receptor 7-Targeted Therapy in Respiratory Disease
}

\author{
Katie M. Lebold David B. Jacoby Matthew G. Drake \\ Pulmonary and Critical Care Medicine, Oregon Health and Science University, Portland, OR, USA
}

\section{Keywords}

Toll-like receptor 7 - Asthma - Allergic rhinitis .

Virus infection

\section{Summary}

Allergic asthma and allergic rhinitis are inflammatory diseases of the respiratory tract characterized by an excessive type-2 T helper cell (Th2) immune response. Tolllike receptor 7 (TLR7) is a single-stranded viral RNA receptor expressed in the airway that initiates a Th1 immune response and has garnered interest as a novel therapeutic target for treatment of allergic airway diseases. In animal models, synthetic TLR7 agonists reduce airway hyperreactivity, eosinophilic inflammation, and airway remodeling while decreasing Th2-associated cytokines. Furthermore, activation of TLR7 rapidly relaxes airway smooth muscle via production of nitric oxide. Thus, TLR7 has dual bronchodilator and anti-inflammatory effects. Two TLR7 ligands with promising pharmacologic profiles have entered clinical trials for the treatment of allergic rhinitis. Moreover, TLR7 agonists are potential antiviral therapies against respiratory viruses. TLR7 agonists enhance influenza vaccine efficacy and also reduce viral titers when given during an active airway infection. In this review, we examine the current data supporting TLR7 as a therapeutic target in allergic airway diseases.

(c) 2016 S. Karger GmbH, Freiburg

\section{Introduction}

Human airways are repeatedly exposed to invading pathogens. To combat these threats, the airways mount a variety of innate and adaptive immune responses. Microbes are first detected in the airway by several different classes of pattern recognition receptors, one of which is Toll-like receptors (TLRs). Ten different TLRs have been identified in humans, each recognizing different viral, bacterial, fungal or protozoan microbial ligands. TLR ligation triggers the production of pro-inflammatory cytokines and interferons. In this review we focus on TLR7, first recognized as a receptor for viral single-stranded RNA. We examine its potential as a therapeutic immunomodulatory target in asthma, its recently identified function as a bronchodilator, and its role in vaccine development.

\section{TLR7 Expression, Signaling and Ligands}

TLR7 is located in endosomes [1] and recognizes singlestranded viral RNA [2,3]. Viral entry into endosomes occurs via endocytosis and autophagy [4]. Plasmacytoid dendritic cells constitutively express high levels of TLR7 and are the primary source of interferon alpha (IFN- $\alpha$ ) following TLR7 activation [5]. B cells express low levels of TLR7 [6] and undergo proliferation and classswitching in response to TLR7 agonists [7]. Monocytes [8], eosinophils [9], NK cells [10], CD8+ T cells [11], and CD4+ T cells [12] also express TLR7. Activation of TLR7 in leukocytes initiates a MyD88-NFkB signaling cascade and robust production of type-1 $\mathrm{T}$ helper cell(Th1)-related antiviral and pro-inflammatory cytokines, including IFN- $\alpha$, tumor necrosis factor alpha (TNF- $\alpha$ ), interleukin 12 (IL-12), and IL-6 [2, 3].

TLR7 is also expressed by airway epithelial cells in a peri-nuclear distribution [13], and they release IFN- $\beta$ and IFN- $\gamma$ when exposed to the TLR7 agonist resiquimod [14]. Airway nerves express TLR7; however, the localization within neurons is distinct from other cell types. TLR7 is expressed both within the sensory nerve dorsal root ganglion cell body $[15,16]$ and along parasympathetic and sensory nerve axons [17] (fig. 1). TLR7 has also recently been described on the cell surface of B cells [18], and it is likely that axons express TLR7 on the cell surface as well. Stimulation of neu-

\section{KARGER \\ Fax +497614520714

\section{(๑) 2016 S. Karger GmbH, Freiburg}

$1660-3796 / 16 / 0432-0114 \$ 39.50 / 0$
Katie M. Lebold

Pulmonary and Critical Care Medicine

Oregon Health and Science University

3181 SW Sam Jackson Park Rd, Portland, OR 97239-3098 USA

lebold@ohsu.edu 



ronal TLR7 triggers a MyD88-independent pathway and subsequent activation of nociceptors [19]. Neuronal TLR7 activation also leads to the release of nitric oxide (see section below). It is disputed whether or not airway smooth muscle express TLR7 [17, 20, 21]; however, the majority of studies suggest airway smooth muscle does not express TLR7.

TLR7 classically recognizes single-stranded, GU-rich viral RNA. In addition to viral RNA, Hornung et al. [22] showed that some siRNAs activate TLR7, which may complicate the interpretation of studies using siRNA. Endogenous miRNAs such as Let7b [19], Let7c and miR21 [23] also activate TLR7. The ability to distinguish selfversus non-self-RNAs may hinge on endosomal localization of TLR7
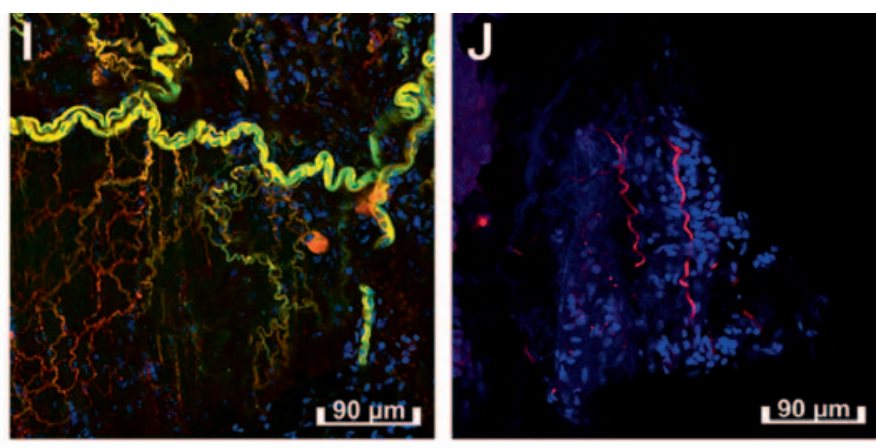

Fig. 1. TLR7 is expressed on a subpopulation of human and murine airway nerves, but not on airway smooth muscle. Whole mounts of human and murine trachea and primary bronchi were immunostained with antibodies to TLR7 (green), the pan-neuronal marker PGP 9.5 (red), and the nuclear stain 49,6-diamidino-2-phenylindole (DAPI) (blue). Both human (A-D) and murine (F-I) airways demonstrated co-localization of TLR7 and PGP 9.5 indicating the presence of TLR7 on specific airway nerves and nerve cell ganglia. TLR7 was not expressed on airway smooth muscle in either species. A, B TLR7 expression on airway nerve bundles. C, D TLR7-positive nerves innervating airway smooth muscle alongside TLR7-negative nerve axons. F Specific nerve cell bodies expressing TLR7. G TLR7-negative nerve cell body alongside TLR7-positive axons. H, I TLR7-positive nerve axons innervating airway smooth muscle. E IgG primary control immunostained with PGP 9.5 and DAPI, but substituting nonspecific IgG for the TLR7 primary antibody, showed minor punctate nonspecific fluorescein binding. $J$ No primary antibody control immunostained with PGP 9.5 and DAPI, but omitting the TLR7 primary antibody showed no fluorescein binding. Images were obtained with a Zeiss laser scanning confocal microscope at 20x and 63x magnification. Reprinted with permission of the American Thoracic Society. Copyright ${ }^{\circledR} 2015$ American Thoracic Society. Cite: Drake MG et al./2013/Toll-like Receptor 7 Rapidly Relaxes Human Airways/American Journal of Respiratory and Critical Care Medicine/188/664-672.The American Journal of Respiratory and Critical Care Medicine is an official journal of the American Thoracic Society.

[24] as well as structural features of the specific RNA [25-27]. A host of synthetic TLR7 ligands also exist. The antiviral and immunomodulating properties of imidazoquinolines were therapeutically recognized before their TLR7 agonist properties were discovered [28]. Imiquimod (R837, S26308) is a TLR7 agonist approved for treatment of anal and genital warts, actinic keratosis, and basal cell carcinoma [29]. Resiquimod (R848, S28463) is a derivative of imiquimod that activates both TLR7 and TLR8 (another viral single-stranded RNA receptor) [30] and more potently induces TNF- $\alpha$ and IL-12 secretion [29] when compared with imiquimod. Gardiquimod [31], 3M-019 [32], CL097 [33], S-27609 [34], MEDI9197 (clinicaltrials. gov NCT02556463), and 852A [35] are also imidazoquinoline TLR7 
Fig. 2. Therapeutic effects of TLR7 agonists. A Asthma is characterized by excessive Th2-related inflammation including airway eosinophilia and elevated production of IL-4, IL-5, and IL-13. TLR7 agonists activate dendritic cells (DCs), airway epithelial cells (AECs), and Th1 cells to induce Th1 immune polarization that reduces airway hyperreactivity and airway remodeling. B Airway nerves express TLR7 and upon activation release nitric oxide (NO) to cause airway smooth muscle relaxation and bronchodilation.
A

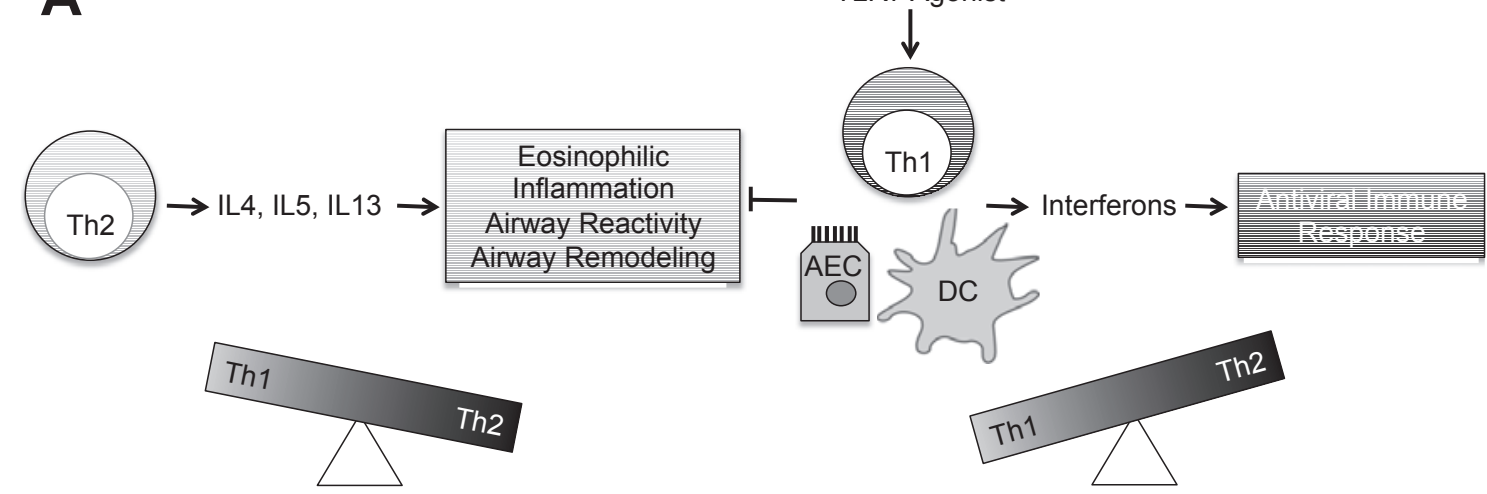

B

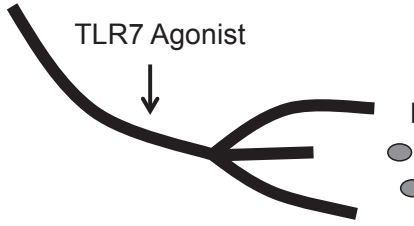

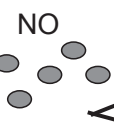

agonists, while the guanosine analogues Loxoribine [36], and ANA773 [37] as well as the adenine analogues SM-324405 [38], AZ12441970 [38], GSK2245035 [39], AZD8848 [40], and GS-9620 [41] also activate TLR7. Three synthetic oligonucleotide TLR7 antagonists are currently in preclinical and clinical trials: DV1179 (dynavax.com), IMO-8400 and IMO-3100 [42].

\section{Targeting TLR7 in Asthma}

Asthma is characterized by airflow limitation due to excessive bronchoconstriction, mucus hypersecretion and airway hyperreactivity (an abnormal tendency to constrict in response to stimuli that do not cause bronchoconstriction in non-asthmatic patients). While asthma is a heterogeneous disease, almost two-thirds of asthmatics have excessive type-2 T helper cell(Th2)-related inflammation characterized by airway eosinophilia and elevated production of IL-4, IL-5, IL-13, and IgE [43]. Until recently, asthma treatment consisted of reversing airflow obstruction with bronchodilators and reducing airway inflammation with inhaled and systemic corticosteroids. However, treatments targeting IgE (omalizumab) [44] and IL-5 (mepolizumab) [45] have recently been introduced as novel strategies to address Th2 inflammation. Further development of targeted therapies offers hope to the nearly $10 \%$ of asthmatics who have uncontrolled symptoms despite maximal treatment with current medications [46].

\section{Airway Inflammation}

TLR7's immunomodulatory properties have been demonstrated in a variety of preclinical models. Specifically, TLR7 agonists' po- tent induction of Th1 immunity attenuates the excessive Th2 phenotype in allergic asthma and allergic rhinitis (fig. 2). For example, resiquimod given prophylactically or therapeutically reduced inflammatory cell recruitment as well as IL-4, IL-5, IL-13 and IgE levels following allergen challenge in sensitized animals [47-50]. Resiquimod reversed airway reactivity $[47,48,50]$ and prevented airway smooth muscle proliferation and goblet cell hyperplasia following chronic allergen challenge [49]. Thus, TLR7-targeted therapy may prevent both pathologic remodeling of the airway and airflow obstruction. In support of this approach, two recently completed clinical trials evaluated the tolerability and safety of TLR7 agonists for treatment of allergic rhinitis. In a phase IIa study, 60 $\mu \mathrm{g}$ of AZD8848 given once per week before allergen challenge reduced immediate post-challenge rhinitis symptoms as well as morning symptoms for 5 days following treatment [40]. In a randomized, double-blind, placebo-controlled study, $20 \mathrm{ng}$ of GSK2245035 given intranasally was well tolerated by patients. A higher concentration of TLR7 agonist or more frequent dosing caused fevers, headache, myalgia, and nasal irritation [39], reinforcing the importance of characterizing the therapeutic range for these agonists in humans. A once-weekly dosing regimen maintained TLR7's pharmacologic response while avoiding tolerance or excessive immune stimulation. Studies of TLR7 agonists in humans with asthma are also underway. A trial of TLR7 stimulation in patients with mild asthma has been completed (clinicaltrials.gov NCT01607372), and results are pending.

\section{Acute Bronchodilation}

Rapid bronchodilators remain a cornerstone of asthma care. TLR7 agonists acutely relax airway smooth muscle within seconds 
to minutes $[17,51]$, an effect distinct from their ability to inhibit Th2 inflammation. Relaxation is unaffected by eosinophilic airway inflammation and blocked by a nitric oxide synthase inhibitor (LNMMA), indicating that TLR7 induces bronchodilation via the production of nitric oxide (fig. 2). TLR7-mediated nitric oxide release likely occurs in airway nerves since airway smooth muscle does not express TLR7 and airway epithelium was not required for TLR7-mediated bronchodilation. Physiologically, TLR7-mediated release of nitric oxide may serve a protective role in limiting airway constriction during early viral infection and is an attractive pharmacologic target as a novel bronchodilator.

\section{Viral Infections}

Respiratory virus infections exacerbate asthma. Rhinovirus, respiratory syncytial virus, and influenza account for the majority of viruses detected during an acute exacerbation [52]. However, prevention of viral infections and treatment options are limited. Annual influenza vaccination is currently the only routine antiviral preventative measure. This strategy has produced variable results depending on the specificity of the vaccine for a given year's influenza strain [53]. This has led to the search for adjuvants that can augment the immune response to vaccine. In mice, imiquimod administered at the time of vaccination improved morbidity [54] and increased survival following influenza challenge [55]. This effect may be due to enhanced viral antigen uptake and presentation by dendritic cells in the presence TLR7 agonist [56]. Incorporating RNA or 3M-019 into the vaccine also promoted antibody production via the induction of isotype class-switching during influenza challenge $[32,54]$. Furthermore, intranasal delivery of a dual TLR7/TLR8 imidazoquinoline agonist 3M-011, given either before influenza infection or after inoculation, reduced influenza virus titers in the lung of rats [57]. TLR7's antiviral effects have potential for both prevention and treatment of influenza infection.

\section{Safety Profile and Future Studies}

TLR7 agonists' dual activity as an acute bronchodilator coupled with chronic attenuation of Th2-related inflammation offers a therapeutic profile unique from current bronchodilators.

However, the potential for TLR7 agonists to stimulate Th1 immune responses necessitates a thorough evaluation of their therapeutic dosing range in human studies. Furthermore, allergic airway diseases have heterogeneous phenotypes that will require careful classification in order to identify who will benefit from TLR7 agonist treatment. To this point, intranasal delivery of TLR7 agonists in non-allergic animal models is pro-inflammatory and causes airway neutrophilia, while TLR7 agonist suppresses airway eosinophilia without causing airway neutrophilia in allergic animals [48]. Similarly, a subset of healthy volunteers and patients with allergic rhinitis experienced transient elevation of blood neutrophil counts following intranasal TLR7 treatment [39]. Thus patients with eosinophilia and/or other markers of a Th2 phenotype should be selected for TLR7 trials, similar to an approach used for the recently approved anti-IL5 drug mepolizumab [58], with close attention paid to Th1-related side effects.

\section{Conclusions}

TLR7 is a clinically attractive therapeutic target as an acute bronchodilator, as a chronic anti-inflammatory mediator, and as an antiviral therapy against influenza. While TLR7 agonists require more thorough evaluation in humans, aerosolized TLR7 agonists with limited systemic absorption are promising treatment options for respiratory diseases.

\section{Disclosure Statement}

The authors of have no conflicts of interest to declare.

\section{References}

1 Nishiya T, DeFranco AL: Ligand-regulated chimeric receptor approach reveals distinctive subcellular localization and signaling properties of the Toll-like receptors. J Biol Chem 2004;279:19008-19017.

2 Heil F, Hemmi H, Hochrein H, Ampenberger F, Kirschning C, Akira S, Lipford G, Wagner H, Bauer S: Species-specific recognition of single-stranded RNA via Toll-like receptor 7 and 8. Science 2004;303:15261529.

3 Diebold SS, Kaisho T, Hemmi H, Akira S, Reis e Sousa C: Innate antiviral responses by means of TLR7-mediated recognition of single-stranded RNA. Science 2004;303:1529-1531.

4 Lee HK, Lund JM, Ramanathan B, Mizushima N, Iwasaki A: Autophagy-dependent viral recognition by plasmacytoid dendritic cells. Science 2007;315:13981401.
5 Ito T, Amakawa R, Kaisho T, Hemmi H, Tajima K, Uehira K, Ozaki Y, Tomizawa H, Akira S, Fukuhara S: Interferon-alpha and interleukin-12 are induced differentially by Toll-like receptor 7 ligands in human blood dendritic cell subsets. J Exp Med 2002;195:15071512 .

6 Hornung V, Rothenfusser S, Britsch S, Krug A, Jahrsdorfer B, Giese T, Endres S, Hartmann G: Quantitative expression of Toll-like receptor 1-10 mRNA in cellular subsets of human peripheral blood mononuclear cells and sensitivity to CPG oligodeoxynucleotides. J Immunol 2002;168:4531-4537.

7 Glaum MC, Narula S, Song D, Zheng Y, Anderson AL, Pletcher $\mathrm{CH}$, Levinson AI: Toll-like receptor 7-induced naive human B-cell differentiation and immunoglobulin production. J Allergy Clin Immunol 2009; 123:224-230 e224.
8 Applequist SE, Wallin RP, Ljunggren HG: Variable expression of Toll-like receptor in murine innate and adaptive immune cell lines. Int Immunol 2002;14: 1065-1074.

9 Nagase H, Okugawa S, Ota Y, Yamaguchi M, Tomizawa H, Matsushima K, Ohta K, Yamamoto K, Hirai $\mathrm{K}$ : Expression and function of Toll-like receptors in eosinophils: activation by Toll-like receptor 7 ligand. J Immunol 2003;171:3977-3982.

10 Hart OM, Athie-Morales V, O'Connor GM, Gardiner CM: TLR7/8-mediated activation of human NK cells results in accessory cell-dependent IFN-gamma production. J Immunol 2005;175:1636-1642. 
11 Song Y, Zhuang Y, Zhai S, Huang D, Zhang Y, Kang W, Li X, Liu Q, Yu Q, Sun Y: Increased expression of TLR7 in CD8(+) T cells leads to TLR7-mediated activation and accessory cell-dependent IFN-gamma production in HIV type 1 infection. AIDS Res Hum Retroviruses 2009;25:1287-1295.

12 Dominguez-Villar M, Gautron AS, de Marcken M, Keller MJ, Hafler DA: TLR7 induces anergy in human CD4(+) T cells. Nat Immunol 2015;16:118-128.

13 Shikhagaie MM, Andersson CK, Mori M, Kortekaas Krohn I, Bergqvist A, Dahl R, Ekblad E, Hoffmann HJ, Bjermer L, Erjefalt JS: Mapping of TLR5 and TLR7 in central and distal human airways and identification of reduced TLR expression in severe asthma. Clin Exp Allergy 2014;44:184-196.

14 Sykes A, Edwards MR, Macintyre J, del Rosario A, Bakhsoliani E, Trujillo-Torralbo MB, Kon OM, Mallia P, McHale M, Johnston SL: Rhinovirus 16-induced IFN-alpha and IFN-beta are deficient in bronchoalveolar lavage cells in asthmatic patients. J Allergy Clin Immunol 2012;129:1506-1514 e1506.

15 Helley MP, Abate W, Jackson SK, Bennett JH, Thompson SW: The expression of Toll-like receptor 4, 7 and co-receptors in neurochemical sub-populations of rat trigeminal ganglion sensory neurons. Neuroscience 2015;310:686-698.

16 Liu T, Xu ZZ, Park CK, Berta T, Ji RR: Toll-like receptor 7 mediates pruritus. Nat Neurosci 2010;13:14601462.

17 Drake MG, Scott GD, Proskocil BJ, Fryer AD, Jacoby DB, Kaufman EH: Toll-like receptor 7 rapidly relaxes human airways. Am J Respir Crit Care Med 2013;188: 664-672.

18 Kanno A, Tanimura N, Ishizaki M, Ohko K, Motoi Y, Onji M, Fukui R, Shimozato T, Yamamoto K, Shibata T, Sano S, Sugahara-Tobinai A, Takai T, Ohto U, Shimizu T, Saitoh S, Miyake K: Targeting cell surface TLR7 for therapeutic intervention in autoimmune diseases. Nat Commun 2015;6:6119.

19 Park CK, Xu ZZ, Berta T, Han Q, Chen G, Liu XJ, Ji RR: Extracellular microRNAs activate nociceptor neurons to elicit pain via TLR7 and TRPA1. Neuron 2014; 82:47-54.

20 Mansson Kvarnhammar A, Tengroth L, Adner M, Cardell LO: Innate immune receptors in human airway smooth muscle cells: Activation by TLR1/2, TLR3, TLR4, TLR7 and NOD1 agonists. PLoS One 2013;8: e68701.

21 Morris GE, Parker LC, Ward JR, Jones EC, Whyte MK, Brightling CE, Bradding P, Dower SK, Sabroe I: Cooperative molecular and cellular networks regulate Tolllike receptor-dependent inflammatory responses. FASEB J 2006;20:2153-2155

22 Hornung V, Guenthner-Biller M, Bourquin C, Ablasser A, Schlee M, Uematsu S, Noronha A, Manoharan M, Akira S, de Fougerolles A, Endres S, Hartmann G: Sequence-specific potent induction of IFNalpha by short interfering RNA in plasmacytoid dendritic cells through TLR7. Nat Med 2005;11:263-270.

23 Liu HY, Huang CM, Hung YF, Hsueh YP: The microRNAs Let7c and miR21 are recognized by neuronal Toll-like receptor 7 to restrict dendritic growth of neurons. Exp Neurol 2015;269:202-212.

24 Barton GM, Kagan JC, Medzhitov R: Intracellular localization of Toll-like receptor 9 prevents recognition of self DNA but facilitates access to viral DNA. Nat Immunol 2006;7:49-56.

25 Gantier MP, Tong S, Behlke MA, Irving AT, Lappas M, Nilsson UW, Latz E, McMillan NA, Williams BR: Rational design of immunostimulatory siRNAs. Mol Ther 2010;18:785-795.
26 Sioud M, Furset G, Cekaite L: Suppression of immunostimulatory siRNA-driven innate immune activation by 2'-modified RNAs. Biochem Biophys Res Commun 2007;361:122-126.

27 Kariko K, Buckstein M, Ni H, Weissman D: Suppression of RNA recognition by Toll-like receptors: the impact of nucleoside modification and the evolutionary origin of RNA. Immunity 2005;23:165-175.

28 Harrison CJ, Jenski L, Voychehovski T, Bernstein DI: Modification of immunological responses and clinical disease during topical R-837 treatment of genital HSV-2 infection. Antiviral Res 1988;10:209-223.

29 Hemmi H, Kaisho T, Takeuchi O, Sato S, Sanjo H, Hoshino K, Horiuchi T, Tomizawa H, Takeda K, Akira S: Small anti-viral compounds activate immune cells via the TLR7 MyD88-dependent signaling pathway. Nat Immunol 2002;3:196-200.

30 Jurk M, Heil F, Vollmer J, Schetter C, Krieg AM, Wagner H, Lipford G, Bauer S: Human TLR7 or TLR8 independently confer responsiveness to the antiviral compound R-848. Nat Immunol 2002;3:499.

31 Ma F, Zhang J, Zhang J, Zhang C: The TLR7 agonists imiquimod and gardiquimod improve DC-based immunotherapy for melanoma in mice. Cell Mol Immunol 2010;7:381-388.

32 Johnston D, Zaidi B, Bystryn JC: TLR7 imidazoquinoline ligand $3 \mathrm{M}-019$ is a potent adjuvant for pure protein prototype vaccines. Cancer Immunol Immunother 2007;56:1133-1141

33 Di Domizio J, Blum A, Gallagher-Gambarelli M, Molens JP, Chaperot L, Plumas J: TLR7 stimulation in human plasmacytoid dendritic cells leads to the induction of early IFN-inducible genes in the absence of type I IFN. Blood 2009;114:1794-1802.

34 Doxsee CL, Riter TR, Reiter MJ, Gibson SJ, Vasilakos JP, Kedl RM: The immune response modifier and Tolllike receptor 7 agonist S-27609 selectively induces IL-12 and TNF-alpha production in CD11c+CD11b+ CD8- dendritic cells. J Immunol 2003;171:1156-1163.

35 Dudek AZ, Yunis C, Harrison LI, Kumar S, Hawkinson R, Cooley S, Vasilakos JP, Gorski KS, Miller JS: First in human phase I trial of 852a, a novel systemic Toll-like receptor 7 agonist, to activate innate immune responses in patients with advanced cancer. Clin Cancer Res 2007;13:7119-7125.

36 Heil F, Ahmad-Nejad P, Hemmi H, Hochrein H, Ampenberger F, Gellert T, Dietrich H, Lipford G, Takeda K, Akira S, Wagner H, Bauer S: The Toll-like receptor 7 (TLR7)-specific stimulus loxoribine uncovers a strong relationship within the TLR7, 8 and 9 subfamily. Eur J Immunol 2003;33:2987-2997.

37 Bergmann JF, de Bruijne J, Hotho DM, de Knegt RJ, Boonstra A, Weegink CJ, van Vliet AA, van de Wetering J, Fletcher SP, Bauman LA, Rahimy M, Appleman JR, Freddo JL, Janssen HL, Reesink HW: Randomised clinical trial: anti-viral activity of ANA773, an oral inducer of endogenous interferons acting via TLR7, in chronic HCV. Aliment Pharmacol Ther 2011;34:443453.

38 Biffen M, Matsui H, Edwards S, Leishman AJ, Eiho K, Holness E, Satterthwaite G, Doyle I, Wada H, Fraser NJ, Hawkins SL, Aoki M, Tomizawa H, Benjamin AD, Takaku H, McInally T, Murray CM: Biological characterization of a novel class of Toll-like receptor 7 agonists designed to have reduced systemic activity. $\mathrm{Br} \mathrm{J}$ Pharmacol 2012;166:573-586.

39 Tsitoura D, Ambery C, Price M, Powley W, Garthside S, Biggadike K, Quint D: Early clinical evaluation of the intranasal TLR7 agonist GSK2245035: use of translational biomarkers to guide dosing and confirm target engagement. Clin Pharmacol Ther 2015;98:369-380.
40 Greiff L, Ahlstrom-Emanuelsson C, Alenas M, Almqvist G, Andersson M, Cervin A, Dolata J, Lindgren S, Martensson A, Young B, Widegren H: Biological effects and clinical efficacy of a topical Toll-like receptor 7 agonist in seasonal allergic rhinitis: a parallel group controlled phase IIa study. Inflamm Res 2015;64:903915.

41 Gane EJ, Lim YS, Gordon SC, Visvanathan K, Sicard E Fedorak RN, Roberts S, Massetto B, Ye Z, Pflanz S, Garrison KL, Gaggar A, Mani Subramanian G, McHutchison JG, Kottilil S, Freilich B, Coffin CS, Cheng W, Kim YJ: The oral Toll-like receptor-7 agonist GS-9620 in patients with chronic hepatitis B virus infection. J Hepatol 2015;63:320-328.

42 Suarez-Farinas M, Arbeit R, Jiang W, Ortenzio FS, Sullivan T, Krueger JG: Suppression of molecular inflammatory pathways by Toll-like receptor 7,8 , and 9 antagonists in a model of IL-23-induced skin inflammation. PLoS One 2013;8:e84634.

43 Wenzel SE: Asthma phenotypes: the evolution from clinical to molecular approaches. Nat Med 2012;18: 716-725.

44 Busse W, Corren J, Lanier BQ, McAlary M, FowlerTaylor A, Cioppa GD, van As A, Gupta N: Omalizumab, anti-IgE recombinant humanized monoclonal antibody, for the treatment of severe allergic asthma. J Allergy Clin Immunol 2001;108:184-190.

45 Ortega HG, Liu MC, Pavord ID, Brusselle GG, FitzGerald JM, Chetta A, Humbert M, Katz LE, Keene ON, Yancey SW, Chanez P, Investigators M: Mepolizumab treatment in patients with severe eosinophilic asthma. N Engl J Med 2014;371:1198-1207.

46 Chung KF, Wenzel SE, Brozek JL, Bush A, Castro M, Sterk PJ, Adcock IM, Bateman ED, Bel EH, Bleecker ER, Boulet LP, Brightling C, Chanez P, Dahlen SE, Djukanovic R, Frey U, Gaga M, Gibson P, Hamid Q, Jajour NN, Mauad T, Sorkness RL, Teague WG: International ERS/ATS guidelines on definition, evaluation and treatment of severe asthma. Eur Respir J 2014;43: 343-373.

47 Van LP, Bardel E, Gregoire S, Vanoirbeek J, Schneider E, Dy M, Thieblemont N: Treatment with the TLR7 agonist R848 induces regulatory T-cell-mediated suppression of established asthma symptoms. Eur J Immunol 2011;41:1992-1999.

48 Xirakia C, Koltsida O, Stavropoulos A, Thanassopoulou A, Aidinis V, Sideras P, Andreakos E: Toll-like receptor 7-triggered immune response in the lung mediates acute and long-lasting suppression of experimental asthma. Am J Respir Crit Care Med 2010;181: 1207-1216.

49 Camateros P, Tamaoka M, Hassan M, Marino R, Moisan J, Marion D, Guiot MC, Martin JG, Radzioch $\mathrm{D}$ : Chronic asthma-induced airway remodeling is prevented by Toll-like receptor-7/8 ligand S28463. Am J Respir Crit Care Med 2007;175:1241-1249.

50 Moisan J, Camateros P, Thuraisingam T, Marion D, Koohsari H, Martin P, Boghdady ML, Ding A, Gaestel M, Guiot MC, Martin JG, Radzioch D: Tlr7 ligand prevents allergen-induced airway hyperresponsiveness and eosinophilia in allergic asthma by a MyD88-dependent and MK2-independent pathway. Am J Physiol Lung Cell Mol Physiol 2006;290:L987-995.

51 Kaufman EH, Fryer AD, Jacoby DB: Toll-like receptor 7 agonists are potent and rapid bronchodilators in guinea pigs. J Allergy Clin Immunol 2011;127:462469.

52 Johnston SL, Pattemore PK, Sanderson G, Smith S, Lampe F, Josephs L, Symington P, O’Toole S, Myint $\mathrm{SH}$, Tyrrell DA, et al: Community study of role of viral infections in exacerbations of asthma in 9-11 year old children. BMJ 1995;310:1225-1229. 
53 Tricco AC, Chit A, Soobiah C, Hallett D, Meier G, Chen MH, Tashkandi M, Bauch CT, Loeb M: Comparing influenza vaccine efficacy against mismatched and matched strains: a systematic review and meta-analysis. BMC Med 2013;11:153.

54 Schmitz N, Beerli RR, Bauer M, Jegerlehner A, Dietmeier K, Maudrich M, Pumpens P, Saudan P, Bachmann MF: Universal vaccine against influenza virus: linking TLR signaling to anti-viral protection. Eur J Immunol 2012;42:863-869.
5 Zhang AJ, Li C, To KK, Zhu HS, Lee AC, Li CG, Chan JF, Hung IF, Yuen KY: Toll-like receptor 7 agonist imiquimod in combination with influenza vaccine expedites and augments humoral immune responses against influenza $\mathrm{A}(\mathrm{H} 1 \mathrm{~N} 1)$ pdm09 virus infection in BALB/c mice. Clin Vaccine Immunol 2014;21:570579.

56 Kastenmuller K, Wille-Reece U, Lindsay RW, Trager LR, Darrah PA, Flynn BJ, Becker MR, Udey MC, Clausen BE, Igyarto BZ, Kaplan DH, Kastenmuller W, Germain RN, Seder RA: Protective T cell immunity in mice following protein-TLR7/8 agonist-conjugate immunization requires aggregation, type I IFN, and multiple DC subsets. J Clin Invest 2011;121:1782-1796.
57 Hammerbeck DM, Burleson GR, Schuller CJ, Vasilakos JP, Tomai M, Egging E, Cochran FR, Woulfe S, Miller RL: Administration of a dual Toll-like receptor 7 and Toll-like receptor 8 agonist protects against influenza in rats. Antiviral Res 2007;73:1-11.

58 Pavord ID, Korn S, Howarth P, Bleecker ER, Buhl R, Keene ON, Ortega H, Chanez P: Mepolizumab for severe eosinophilic asthma (DREAM): a multicentre, double-blind, placebo-controlled trial. Lancet 2012; 380:651-659. 